\title{
ГЕОРГИЙ ЕВГЕНЬЕВИЧ ЗАЛЕССКИЙ - АВТОР ЦЕННОСТНО-ДЕЯТЕЛЬНОСТНОГО ПОДХОДА В ИЗУЧЕНИИ ЛИЧНОСТИ (заметки к 95-летнему юбилею со дня рождения)
}

\author{
Е.Б. Редькина \\ Московский гуманитарный университет
}

\begin{abstract}
Аннотация: В статье, посвященной 95-летию со дня рождения выдающегося психолога, исследователя и ученого, Георгия Евгеньевича Залесского, представлены некоторые факты его жизни; основные результаты его научных исследований проблемы становления личностного мировоззрения, имеющих общепсихологическое значение; рассмотрена структура, особенности и возможности разработанного им метода диагностики (иенностно-нормативной методики ЦНМ), возможности его использования в целях формирования и коррекции; перспективы распространения идей ученого на изучение ценностно-смысловых образований личности.

Ключевые слова: Г.Е.Залесский, личностное мировоззрение, убеждение, способ сочиальной ориентировки, иенностно-деятельностный подход, иенностно-нормативная методика
\end{abstract}

\section{G.E. ZALESSKIY - AUTHOR VALUE-BASED APPROACH IN PERSONALITY STUDIES alesskiy (notes for the 95-th Anniversary of his Birth)}

\author{
E.B. Redkina \\ Moscow University for the Humanities
}

\begin{abstract}
The article dedicated to the 95th anniversary of the birth of the outstanding psychologist, researcher and scientist, Georgy Evgenievich Zalessky, presents some facts of his life; the main results of his scientific research on the formation of a personal worldview, which have general psychological significance; the structure, features and capabilities of the diagnostic method developed by him (value-normative methodology - VNM), the possibility of its use for the formation and correction are considered; prospects for the dissemination of the scientist's ideas to the study of the value-semantic formations of the individual
\end{abstract}

Keywords: G.E. Zalessky, personal worldview, conviction, method of social orientation, value-activity approach, value-normative methodology

Залесский Георгий Евгеньевич, известный советский и российский психолог, чуткий наставник, внимательный учитель... Родился в Москве. В документах указано - 11 апреля 1925 года. В разговорах он упоминал, что изменил год рождения, чтобы попасть на фронт. Окончив Первое Военно-Пехотное Краснознаменное училище имени Верховного Совета РСФСР, уходит на фронт, в качестве командира стрелкового взвода 270-й стрелковой дивизии участвует в боевых операциях на 1-м Прибалтийском фронте (1942-1944).

О войне говорить не любил: «Слишком страшно и грязно...», когда показывали «Штрафбат» - придвигал кресло к самому экрану телевизора и вглядывался 
в лица актеров, словно ища кого-то, шевелил губами, продолжая неслышимый окружающим разговор... И потом несколько часов не отвечал на телефонные звонки... Для него война не закончилась в 45-м.

Ранения, госпитали, орден Красного Знамени, медали... Экзамен за среднюю школу он сдал экстерном уже после войны, окончил исторический факультет МГУ им. М.В. Ломоносова, преподавал... Вспоминая о послевоенных и военных годах очень часто спрашивал: «Для чего...? Ради чего...? Во имя чего...?» Какие простые вопросы, но как сложно найти ответы... Размышления о событиях, людях всегда проходили через эти точки - и все становилось понятно. Потому что именно это являлось для Георгия Евгеньевича определяющим.

В 1965 г. Г.Е. Залесский заканчивает аспирантуру по психологии в НИИ общей и педагогической психологии АПН РСФСР (ныне Психологический институт РАО). На его становление как ученого и исследователя повлияли Н.А. Менчинская, Л.Н. Ланда, П.Я.Гальперин. Тема его кандидатской диссертации - «Формирование приемов умственной деятельности (в процессе решения задач на оценку общественных явлений)». Снова и снова он обращается к проблеме связи общественного и личностного: как и когда появляется у человека понимание для чего, ради чего, во имя чего? Каковы механизмы связи между существующими у человека знаниями о социальных нормах и правилах и стремлением руководствоваться ими?

Тема докторской диссертации - «Психологические основы формирования убеждений» (1991). Г.Е. Залесский обращается к проблеме убеждений, личностного мировоззрения. Именно убеждение, являясь единицей мировоззрения, отражает и реализует ценности конкретной личности. Убеждение, по Залесскому, выступает эталоном при выборе мотива в ситуации морального конфликта: поступить как должно или как считаешь необходимым? Личностное убеждение позволяет оценить эти мотивы с позиции личностной допустимости, приемлемости и, если мотив соответствует определенной личностной ценности, то он включается в процесс построения социальной ориентировки. При этом данный мотив приобретает дополнительный личностный смысл, а его реализация сопровождается повышением эмоциональной удовлетворенности, снижением тревожности. Убеждения представляют собой надситуативные образования, надстройку, которая дает возможность использовать научные социальные знания как элемент личного способа социальной ориентировки. Под способом социальной ориентировки автор понимает совокупность обобщенных приемов познавательной деятельности, выполняя которые человек принимает решение о том, как отнестись к той или иной социальной ситуации, выделяя в его структуре когнитивный, операциональный и мотивационный компоненты.

Вклад Георгия Евгеньевича Залесского в психологию связан с разработкой ценностно-деятельностного подхода к исследованию проблемы становления и 
развития личностного мировоззрения. В рамках этого подхода проанализированы материалы о месте и функциях убеждений и собственного мировоззрения в структуре личности, о характере их взаимодействия с другими компонентами. Особое значение Г.Е. Залесский придавал вопросу о возможностях диагностики убеждений, мировоззрения. Дело в том, что в психологии нет единого, общепринятого метода изучения смысловых образований, это связано с рядом причин, одной из которых является традиционное разделение, фрагментарность изучения смысловой сферы личности; предметом диагностики выступают отдельные составляющие (например, особенности ценностей, особенности поведения в ситуации конфликта ценностей, особенности мотивационной сферы). Как следствие этого, представленные в литературе диагностические методики не позволяют выявить целостную картину смысловой сферы личности.

Традиционно для изучения особенностей личностных ценностей в отечественной психологии традиционно применяется «срезовый» метод, при этом представленные в литературе методики могут быть условно разделены на три группы:

- анализ продуктов деятельности, контент-анализ (высказывания, сочинения, дневниковые записи). Методики просты в реализации, однако налицо субъективность в интерпретации результатов, необходима специальная доподготовка исследователя;

- методики, базирующиеся на процедурах ранжирования, шкалирования (различные варианты методики М. Рокич - Ядова, Schwartz). Достоинством методик является универсальность, удобство и экономичность в проведении обследования и обработке результатов, гибкость - возможность варьировать как списки ценностей, так и инструкции. Вместе с тем ответы испытуемых могут определяться социальной установкой испытуемых, интерпретация результатов во многом определяется самим экспериментатором и нет убедительных доказательств надежности и валидности используемого инструментария;

Полученные при помощи указанных методик результаты позволяют выявить особенности мнений, отношений испытуемых, возможно, их систему, но по-прежнему открытыми остаются вопросы о том, когда, в каких случаях заявленные предпочтения выступают как проявление реальных ценностно-смысловых образований; проявляются ли и каким образом могут быть обнаружены/ диагностированы проявления выявленных предпочтений в конкретных формах поведения.

При этом длительное время вопрос о том, что побуждает человека упорядочить (концептуализировать) свои представления о себе, о мире; в каком возрасте, при каких условиях, каковы критерии развитости/сформированности ценностно-смысловых образований, каковы механизмы включения определенного общественного опыта в структуру личностных смысловых образований оставался 
вне поля зрения исследователей. А ведь именно эти вопросы вызывают особый интерес не только теоретиков, но и практических психологов.

Анализируя исследования интегративных смысловых личностных образований (направленность, социальная позиция, мировоззрение и др.), можно отметить следующее:

- имеющиеся теоретические подходы зачастую не «доводились» до уровня реализации в конкретных диагностических методиках;

- используемые же диагностические методики в малой степени опираются на данные, отражающие систему действующих и смыслообразующих мотивов.

В результате возникает разрыв между особенностями присвоенных личностью общественных знаний - ценностей и наблюдаемыми формами конкретного поведения. Кроме этого накопленный в отечественной психологии эмпирический материал зачастую устарел (так как базировался и анализировался в рамках, задаваемых государственной идеологией).

Г.Е. Залесским был разработан «метод вовлечения испытуемых в жизненные ситуации путем систематического изменения условий одной и той же задачи», опирающийся на признание единства наличия знаний и умений применять их в практической деятельности и личной убежденности в такой необходимости.

Основной вид заданий - задачи на ценностно-смысловую ориентировку в личностно значимых ситуациях, которые содержат проблемную ситуацию особого рода - ценностную проблемную ситуацию, включающую конфликт между содержанием мировоззренческих знаний, норм и ценностей, с одной стороны, и «житейским» подходом к проблемам - с другой. Для их выполнения от испытуемых требуется:

1) выбрать систему ценностей (норм, правил, принципов), с помощью которых ими будут оцениваться ситуации (личная и общественная значимость), выбрать мотивы, цели, поступки.

2) решить систему задач, разработанных согласно принципу вовлечения испытуемых в жизненные ситуации (путем изменения условий одной и той же задачи). Это достигается путем использования метода логической «развертки» ситуаций. Каждая из последующих задач включает ситуацию, являющуюся логическим развитием ситуации, приводимой в условии предыдущей задачи. Так, например, если условие первой задачи содержало информацию о событии (поступке), то в условии последующих задач идет речь о различном отношении к нему. Задачи строятся по принципу «развертки», с систематически изменяющимися условиями. Особая роль при этом принадлежит этапу решения испытуемыми задач, включающих «сбивающие» факторы.

С помощью ценностно-нормативной методики - ЦНМ - можно выявить не только спектр мотивов, побуждающих выбирать стратегию конкретного поведения, но и выделить иерархию мотивов, а также характер взаимодействия всех 
основных компонентов ценностно-смысловой ориентировки (когнитивного, мотивационного, поведенческого) в жизненно значимых ситуациях.

Представляется важным указание на многофункциональность ценностно-нормативной методики, где диагностика выступает лишь одной из реализуемых функций. ЦНМ может быть использована в диагностической (Залесский, 1982, 1994; Залесский, Редькина, 1996), формирующей (Редькина, 1992, Салтыкова, 1999) и корректирующей функциях. При этом уже сам процесс диагностики побуждает испытуемых осознавать не только возможные варианты конкретного поведения в той или иной ситуации, но и ставит их перед необходимостью осознавать, рефлексировать причины делаемого выбора.

Г.Е Залесским, его учениками (Питерин Ю.П., Редькина Е.Б., Редя Г.П., Салтыкова О.И., Анисимов В.П., Герасимова А.С., Кучеряну С.Г. и др.) и последователями были реализованы исследования по психодиагностике и коррекции уровней сформированности мировоззрения и убеждений школьников и студентов; прослежена возрастная динамика их развития, получены данные об изменениях в ряде важнейших характеристик самосознания личности в результате формирующегося мировоззрения; рассмотрена связь между характером способа личной ориентировки учащихся (ситуативным, конформным, мировоззренческим) и особенностями построения Я-концепции.

В современном мире проблема присвоения социального опыта, общественных норм сохраняет свою актуальность. Практически любая психологическая проблема сопровождается необходимостью изучения мотивации, соотнесения мотивов действующих и смыслообразующих, понимания того, какие ценности стоят за тем или иным мотивом. И один из вариантов ответов на эти вопросы можно получить изучив, поняв и, возможно, приняв ценностно-деятельностный подход, автор которого - Георгий Евгеньевич Залесский. Человек. Учитель. Ученый.

А мы снова и снова задаем эти вечные вопросы, которые волновали Георгия Евгеньевича Залесского: Для чего? Ради чего? Во имя чего?

\section{СПИСОК ЛИТЕРАТУРЫ}

Залесский Г.Е. (1994) Психология мировоззрения и убеждений личности. М.: МГУ.

Залесский Г.Е. (1982) Психологические вопросы формирования убеждений личности. М.: МГУ.

Залесский Г.Е., Редькина Е.Б. (1996) Психодиагностика убеждений и ориентаций личности: Учеб. пособие /; Моск. гос. ун-т им. М. В. Ломоносова, Фак. психологии. - М.: МГУ.

Разорина Л. М. (2010) Ценностно-нормативный метод Г.Е. Залесского как тех- 
нология исследования в психологии личности // Экспериментальная психология в России: традиции и перспективы. - М.: Институт психологии РАН.

Редькина Елена Борисовна - кандидат психологических наук, доцент, доцент кафедры общей, социальной психологии и истории психологии. Московский гуманитарный университет; 111395, Москва, ул. Юности, д. 5; E-mail: eredkina@mail.ru, тел. $+7(916) 182-4575$.

Redkina Elena Borisovna - PhD (psychology), docent, associate professor of the Department General, Social psychology and History of psychology; Moscow University for the Humanities; 111395, Moscow, Yunosty str. 5; E-mail: eredkina@mail, Tel. $+7(916) 182-4575$

\section{Для цитирования:}

Редькина Е.Б. Георгий Евгеньевич Залесский - автор целостно-деятельностного подхода в изучении личности (заметки к 95-летнему юбилею со дня рождения) // Научные труды Московского гуманитарного университета. 2020. №5. C. 27-32. DOI: https://www.doi. org/10.17805/trudy.2020.5.3 